\title{
Pharmaceuticals in the aquatic environment: sources, effects, treatment methods
}

\author{
Aleksandra Kaleniecka, ${ }^{1}$ Paweł K. Zarzycki ${ }^{1}$ \\ ${ }^{1}$ Department of Toxicology and Bioanalytics, Koszalin University of Technology
}

\begin{abstract}
Residues of daily usage products, including pharmaceuticals and personal care products (PPCPs) as well as pure organic compounds, particularly endocrine-disrupting chemicals (EDCs), can migrate to surface water ecosystems from point sources, e.g. wastewater treatment plants. Although the majority of these substances are present in water at very low concentrations, they started to be considered "new" hazardous environmental pollutants. Their presence in water became an important problem in the late twentieth century, when the production of organic chemicals increased. Certain low-molecular weight organic substances present in water ecosystems at low concentrations are likely to have adverse effects on animals and humans. Even short-term exposures of aquatic organisms to EDCs, especially at early developmental stages, can induce a variety of negative physiological effects. Even though direct negative effects caused by exposure have not been demonstrated, active substances of numerous drugs can accumulate in the tissues and reach higher trophic levels. Modern high-throughput separation and detection techniques, including gas/liquid chromatography coupled with mass spectrometry detectors (GC/LC-MS), allow detecting and quantifying trace amounts of micro-pollutants acting as EDCs in complex biosamples and technological processes, particularly during wastewater treatment. Moreover, limits of detection for many organic micro-pollutants have been determined. New measures to remove pharmaceuticals from sewage should be designed, as many treatment plants are not prepared to effectively eliminate such pollutants. The aim of the present study was to review the literature data regarding the presence of pharmaceuticals, PPCPs and EDCs in the environment (particularly aquatic) and to present the methods of sample determinations and sewage treatment. Additionally, low efficiency of traditional wastewater treatment processes was discussed.
\end{abstract}

Keywords: pharmaceuticals, endocrine disruptors, sewage treatment

\section{Introduction}

\section{Pharmaceuticals in the environment}

Active substances of pharmaceuticals are ubiquitous in the environment, yet only recently they started to be considered hazardous pollutants. Aquatic [1] and soil [2] ecosystems have been found to be particularly sensitive to such substances. The main sources of pollutants are municipal (generated by households) and hospital wastes as well as inadequately utilized, expired medicines, supplements and personal care products. Still another source is animal farms where steroid compounds (acting as growth promoters) and prophylactic antibiotics to prevent possible infections are commonly added to the feed [3].

During recent decades, studies on the effects of pollutants on the aquatic environment focused almost exclusively on priority pollutants, especially toxic and carcinogenic ones. The term "priority substances" was introduced by the Water Framework Directive, in Poland - by the water law. The list of these substances is included in the addendum X to the Water Framework Directive; detailed 
lists of substances and their limit values are determined at the level of legislation of individual member countries. According to the requirements of the Directive, priority substances should be determined cautiously taking into account scientific evaluation of potential risks. Moreover, priority substances include the group of hazardous priority substances, for which complete elimination of discharge and emission is required. While the „ecological policy" should generally restrict the introduction of any substances to natural ecosystems, particularly those impairing their functioning (e.g. biogenes accelerating eutrophization), in the case of priority substances, this policy should be stricter and gradually reduced (according to the principles of balanced development). Moreover, the introduction of hazardous priority substances to ecosystems should be completely eliminated, so their concentrations correspond to natural background concentrations (which is near zero in the case of synthetic substances).

Besides the priority substances listed in the addendum to the Directive, the legislation of member countries can also specify some other substances particularly harmful for the aquatic environment (in Poland, e.g. DDT), whose presence in water can lead to similar actual and legal consequences as the presence of priority substances. The list of priority substances is supplemented according to the current state of knowledge; since 2012, it also includes pharmaceutical active substances, i.e. 17 alpha-ethynylestradiol (EE2), 17 beta-estradiol (E2) and diclofenac. Table 1 presents the list of priority substances included in the addendum to the Water Framework Directive.

The priority substances constitute a small proportion of compounds, which can negatively affect the environment. There is a group of bioactive substances that have only recently been considered environmental pollutants $[4,5]$. This group includes drug ingredients (analgesics, antibiotics, anti-inflammatory drugs, synthetic hormones), active substances in personal care products, nutritive substances, sun protective agents, hormonal promoters of growth and many others. The above substances were chosen mainly due to their potential consequences, such as toxicity in the aquatic environment and mutations inducing the development of drug-resistant bacteria $[6,7,8]$. The compounds in question and their biologically active metabolites are being continuously introduced to the environment $[9,10,11]$. Amongst all the micropollutants that can occur in water and sewage, endocrine disrupting compounds (EDCs) have been of particular interest. They include natural and synthetic chemical compounds impairing the activity of hormones (mainly steroid ones) in humans and animals [12]. Hormones pose a high risk, as well. Ethynylestradiol (EE2) found in contraceptives induces the estrogenic effect already at low concentrations. Fish males exposed to EE2 in a concentration of $4.0 \mathrm{ng} / \mathrm{dm}^{3}$ lose their secondary sex characteristics; moreover, their hormonal balance is impaired, which results in disappearance of gender differences (feminization of males), and ultimately impairs reproduction [13].

The majority of pharmaceuticals are not removed during water treatment, due to their physicochemical properties. Active substances from medicines can accumulate in the tissues and be transferred to higher trophic levels with the food chain, which makes them extremely hazardous to health or life of organisms, including humans. Estrone, estradiol, ethynylestradiol accumulate in the adipose tissue of aquatic organisms. The bioaccumulation factor (BAF) for fish ranges from 2.22 for estrone to 2.83 for ethynylestradiol [14].

The literature data indicate that a definite effect of toxicity for fish, alga and bacteria is observed at a water concentration of pharmaceuticals lower than $1 \mathrm{mg} / \mathrm{dm}^{3}$ [15]. A review by Braush et al. contains thorough information on toxic effects of some selected groups of pharmaceuticals on aquatic organisms. One hundred and 50 substanc- 
es from 35 pharmaceutical groups induced acute toxicity and 65 substances from 20 groups resulted in chronic toxicity. Moreover, the review presents standard and advanced ecotoxicological tests performed on aquatic organisms, demonstrating toxic effects at the molecular level (e.g. inhibition of cyclooxygenase) and at the population level ( changes in behaviour, impact on reproduction) [16]. To date, the studies regarding aquatic fauna (fish, crustaceans, molluscs) have focused on hormones, antibiotics, analgesics and antidepressants. The average water concentrations observed ranged from 0.1 to $100 \mathrm{ng} / \mathrm{g}$ dry mass [17]. The most recent studies concentrate on consequences of exposure to a particular pharmaceutical substance rather than the presence of pharmaceuticals in the environment.

Brodin et al. have found that oxazepam changes the behaviour and feeding efficacy of wild perch (Perca fluviatilis), which is essential for a given population. The authors conclude that antidepressants in surface water can have ecological and evolutionary consequences [18]. Moreover, research regarded the distances to sewage treatment plants to determine the effects of exposure along a concentration gradient. Metcalfe et al. have demonstrated correlations between the introduction of antidepressants to water and accumulation of $\mathrm{Pi}$ mephales promelas in organisms [19]. Fluoxetine is toxic for algae $-\mathrm{EC}_{50}$ ranges from 24 to $4339 \mathrm{mg} /$ $\mathrm{dm}^{3}$ and for bentos $-\mathrm{LC}_{50}-15 \div 43 \mathrm{mg} / \mathrm{kg}$ sediment within 10 days $\left(\mathrm{LC}_{50}\right.$ - medial lethal concentration). The toxicity of sertraline, another antidepressant, for green algae is at $\mathrm{EC}_{50} 12-764 \mathrm{mg} / \mathrm{dm}^{3}$ [20].

Diclofenac, an extremely popular drug, is characterized by the highest toxicity amongst non-steroidal anti-inflammatory drugs and shows chronic toxicity. Laboratory tests performed in rainbow trout (O.mykiss) have revealed acute hepatotoxicity of the drug as well as renal and branchial lesions (testing was carried out in acute toxicity, the exposure to the therapeutic substance was 28 days [21].

\section{Concentrations of the selected substances in the environment}

Not all active substances that get to treatment plants with sewage are completely removed during biological purification. The mean concentration of acetylsalicylic (ASA) acid in wastewater in Germany was $0.22 \mathrm{~g} / \mathrm{dm}^{3}$ [22]. In surface waters, concentrations were below the limit of detection. However, ASA readily transforms into its more active form - salicylic acid, ortho-hydroxyhippuric acid and gentianic acid metabolite. ASA metabolites were detected in samples of influent sewage in concentrations of $54 \mu \mathrm{g} / \mathrm{dm}^{3}, 6.8 \mu \mathrm{g} /$ $\mathrm{dm}^{3}, 4.6 \mu \mathrm{g} / \mathrm{dm}^{3}$, respectively [23]. Moreoevr, effective removal of the majority of active substances studied by purification of municipal wastewater was observed; only salicylic acid was detected in very low concentrations in sewage and rivers. On the other hand, substantially higher concentrations of salicylic acid were determined in sewage in Greece and Spain ( up to $13 \mu \mathrm{g} / \mathrm{dm}^{3}$ ) $[24,25]$, which could be caused by the use of ASA as a keratolytic agent in dermocosmetics and as natural food preservative [26]. A popular drug, paracetamol ( $\mathrm{N}$-(4-hydroxyfenyl) acetamide) is also easily decomposed and removed by sewage treatment. In Germany, paracetamol was detected in less than $10 \%$ of sewage and was not detected in river water containing treated wastewater [22]. In the United Stated, in the study of 142 underflows sensitive to municipal sewage pollutants, paracetamol was detected in $17 \%$ of all samples of max. concentration of $10 \mu \mathrm{g} / \mathrm{dm}^{3}$ [27]. During long-term study monitoring waste and surface water samples in Berlin, diclofenac was detected, the maximum concentration $(3.02 \mu \mathrm{g} / \mathrm{dm} 3)$ was found in influent water while the lowest level ( $2.51 \mu \mathrm{g} /$ $\mathrm{dm}^{3}$ ) in effluent water. The low index of removal, only $17 \%$, shows inability of treatment plants to effectively remove this active substance, which was confirmed by $[28,29]$. Moreover, diclofenac is often detected in the amounts below $\mu \mathrm{g} / \mathrm{dm}^{3}$ in 
sewage and surface waters in Austria, Brazil, Germany, Greece, Spain, Switzerland and the United States [30,31,22,28,32].

Ibuprofen is broken down in the human body to metabolites, which together with the basic form occur in water and sewage $[33,34]$. Although ibuprofen was found to be removed during sewage treatment, particularly carboxy-ibuprofen, the concentration of carboxy-ibuprofen remained at the similar level as that in the influent. The concentrations of ibuprofen in municipal sewage and rivers were lower, compared to concentrations of diclofenac [31]. In Spain, the concentrations of ibuprofen in samples of wastewaters were found to be $1.5 \mu \mathrm{g} / \mathrm{dm}^{3}, 0.87 \mu \mathrm{g} / \mathrm{dm}^{3}$ and $85.0 \mu \mathrm{g} / \mathrm{dm}^{3}$. In the same study, its high concentration, up to $2.5 \mu \mathrm{g} /$ $\mathrm{dm}^{3}$, was detected in surface waters.

Numerous studies were carried out, e.g. in Germany [35], Switzerland [36] and USA [37], to search for the presence of antibacterial drugs in surface waters and sewage. The levels of macrolide antibiotics, clarithromycin, dehydroerythromycin (erythromycin metabolite), roxithromycin, lincomycin, sulphonamides (sulfamethoxazole, sulfadimethoxine and sulfathiazole), fluoroquinolones (ciprofloxacin, norfloxacin and enrofloxacin), chloramphenicol, tylosin and trimethoprim, were low $\left(\mu / \mathrm{dm}^{3}\right)$ in samples of sewage and surface waters. Moreover, penicillin was not detected in surface and underground waters, as it is readily hydrolysed [10].

Due to their hydrophilic properties, the majority of pharmaceuticals are retained very well in sewage systems. Polar groups (carboxyl, aldehyde and amine) of these compounds can interact with organic substances contained in sewage and cause increases in concentrations of pharmaceutical substances in sewage sludge [39]. Since no effective analytical methods have been available, the majority of studies concentrated on detection of pharmaceuticals in sewage [40]. Therefore, most of biological treatment plants show high efficiency in removal of drugs, resulting from sorption and sedimentation of these products from the sludge [15]. Drugs accumulated in sludge are likely will probably be carried to the terrestrial environment, causing serious environmental problems [41]. The studies have revealed that levels of drugs in sewage sludge ranged from several $\mu \mathrm{g} / \mathrm{kg}$ to $\mathrm{mg} / \mathrm{kg}$, depending on collection sites and properties of the compound [42]. Due to possible bacterial mutations, the attention was mainly paid to antibiotics [44]. Study findings have demonstrated that tetracyclines, fluoroquinolones, sulphonamides and macrolides are the key groups of antibiotics detected in sludge samples in the United States [43] and Canada [42].

\section{Quantitative determinations (analytical methods)}

The majority of studies on drugs in sludge were confined to the development of analytical methods and devices in individual treatment plants [45]; therefore, the data regarding the presence of pharmaceuticals in sludge are scarce. Pharmaceutical in sludge should be studied more thoroughly due to their high concentrations and potentially negative effects on humans and animals [46]. The essential element of analyte quantification in complex matrices of environmental samples is the selection of an appropriate method of separation of chemically similar pharmaceuticals and the use of suitably sensitive and selective detectors (allowing determining even very low concentrations of pharmaceuticals in the presence of substances of similar physicochemical properties).

The use of technologically advanced devices for single- and multi-dimensional separation, in particular, gas chromatography and liquid chromatography coupled with various types of mass spectrometers ( i.e. MS-MS, APCI-MS, ESI-MS, CE-MS), enabled to detect various compounds, including drugs, in matrices of environmental samples. MS-MS detection is currently often 
used due to increased analytical sensitivity and selectivity in complex matrices, such as sewage. GC-MS allows determination of such therapeutic substances as diclofenac, diazepam, ibuprofen, naproxen, and acetylsalicylic acid [47]. Thanks to LC-MS, antibiotics (penicillins, tetracyclines, sulphonamides, macrolides), ciprofloxacin, norfloxacin, naproxen, diclofenac, ibuprofen, diazepam can be determined [48]. Thin layer chromatography and immunochemical methods are applied less commonly [49].

\section{Treatment of pharmaceutical-contaminated sewage}

At present, the majority of municipal treatment plants are not appropriately prepared to remove drugs and their metabolites in mechanical and biological processes [50]. Conventional biological wastewater treatment plants use three-chamber biological reactors (denitrification, aerobic and anoxic chamber) or SBR reactors. During traditional biological treatment, thanks to changeable conditions in the chambers, microorganisms of active sludge remove contaminants by decomposing into simpler substances or using as building materials and reserves. SBR reactors are often applied for removal of drugs under laboratory conditions [51]. Moreover, membrane bioreactors are increasingly common. The membrane technology is considered to be the most effective in removing various contaminants flowing into treatment plants.

Furthermore, studies to evaluate the effectiveness of membrane methods have recently been carried out [52]. The membrane module is integrated with the device consisting of suitably coupled media streams of a classical bioreactor and the membrane separation centre.

In water treatment technologies, pressure techniques of membrane separation, e.g. microfiltration, ultrafiltration, and processes using electrical energy (e.g. electrodialysis) are most commonly used [52]. The essence of the process is to separate water or sewage (which are a solvent) from the substances analysed. The stream of water or sewage is passed through the semi-permeable membrane, where the solvent is separated from the contaminant. Membrane reactors are characterised by high effectiveness in removing bacteria and high quality of an eluate. Moreover, they enable to reduce the required area even by $50 \%$, compared to biological reactors, and show a low consumption of energy. Sewage treatment can be improved by using modern method, such as UV exposure with chlorination or ozonation. Ozonation is an effective method for removal of micro-contaminants caused by diclofenac, carbamazepine and sulfamethoxazole [52].

The other effective methods of removal of toxic contaminants from sewage are photodegradation processes (photocatalytic oxidation) with the use of sunlight, UV radiation or photocatalysts) metal oxides, e.g.. $\mathrm{TiO}_{2}, \mathrm{ZnO}, \mathrm{SnO}_{2}$, and sulphates, e.g. $\mathrm{ZnS}, \mathrm{CdS})$. Photocatalysis is a free radical process, causing the formation of highly reactive hydroxyl radicals $(\mathrm{OH})$, which are poorly selective and capable of decomposition of a huge number of organic compounds. The products of degradation are intermediate substances, $\mathrm{CO}_{2}$ and $\mathrm{H}_{2} \mathrm{O}$, and inorganic compounds [55]. $\mathrm{TiO}_{2}$, characterised by high phytochemical stability, activity and resistance to changes in reaction environment, is most widely used [56]. Moreover, adsorption methods are commonly applied due to their high effectiveness in drug removal [57].

The study on removal of ibuprofen using active carbon obtained from cork waste, active carbon was activated chemically with water vapour and $\mathrm{K}_{2} \mathrm{CO}_{3}$ as well as with $\mathrm{K}_{2} \mathrm{CO}_{3}$ alone. Carbon activated with water vapour and $\mathrm{K}_{2} \mathrm{CO}_{3}$ was characterised by higher adsorption capacity due to more developed microporous structure. The assets of this method also include a wide range of operation, pH 2-11 and easy recovery ( even up 
to $100 \%$ ) [58]. A high effectiveness in reposing naproxen was observed while using the material made of apricot wastes, activated with $\mathrm{ZnCl}_{2}$ [59]. The use of powdered activated carbon (PAC), 1 $\mathrm{g} / \mathrm{dm}^{3}$ in the membrane bio-activator to remove pharmaceuticals from sewage enabled to reduce ChZT by $95 \%$, ammonium nitrogen by $70-80 \%$, and phosphorus by about $80 \%$ [60]. He effectiveness depended on the kind of pharmaceutical removed. Moreover, granular active carbon )GAC) was applied. However, the process wad found to be less effective due to competition with other organic compounds present in sewage [61].

Another group of widely used absorbents is clays, i.e. montmorllonite, bentonites with quaternary ammonium cations - the micro-porous materials modified with $\mathrm{CO}^{2+}, \mathrm{Cu}^{2+}$ or $\mathrm{Ni}^{2+}[62]$. The above additives increased the efficiency of removal of salicylic and clofibric acid, carbamabazepines and caffeine. Furthermore, aliphatic polyamides [63] were studied as effective adsorbents of ethynylestradiol (EE2); the findings are comparable to the use of commercial AMBERLTEXAD 4, despite of non-porous structure and a markedly smaller area. The use of 24.1L deposit containing 1.0g PA612 and contact with EE2 for 0.8-1.0 min, enabled the removal of $30 \mathrm{mg} / \mathrm{dm}^{3}$ ethynylestradiol to the levels below the limit of HPLC detection. Still another group of absorbents is silica. Mesoporous MCM-41 silicates containing $\mathrm{Ni}^{2+}$ demonstrated high effectiveness in removing naproxen from water [64].

\section{Summary}

Numerous studies focusing on consequences of occurrence of pharmaceuticals in the environment have been published. Their findings demonstrate many adverse effects of the presence of drugs and personal care products on different organisms. Environmental pharmaceuticals has been considered a global issue and not only concerning developed countries. The majority of people are not aware of dangers resulting from continuous and uncontrolled supply of drugs into aquatic ecosystems. Many widely available pharmaceuticals have been detected in treated sewage as well as surface and ground water in the concentration of up to $\mathrm{mg} / \mathrm{dm}^{3}$. Since standard methods of treatment cannot remove the pharmaceuticals, personal care products (PPCPs) or endocrine-disrupting compounds (EDCs) from sewage and surface waters, new and effective methods of water and sewage treatment should be searched for. At present, the studies focus on membrane, photocatalytic oxidation and adsorption methods. Unfortunately, the technologies used currently are effective only for removal of some groups of pharmaceuticals. It is essential to analyse thoroughly the occurrence of active pharmaceutical substances in sludge in order to eliminate the migration of these compounds to the soil. A multi-level approach to studies regarding consequences of occurrence of drugs in the environment and their effects on organism, especially in aquatic ecosystems, is needed. 
Table 1. List of water policy priority substances with suggested amendments (Journal of Law of the European Union of 24.122008 [65]

\begin{tabular}{|c|c|c|}
\hline Water policy priority substances & $\begin{array}{l}\text { Substances that can be potentially } \\
\text { considered as priority or hazardous } \\
\text { priority substances }\end{array}$ & $\begin{array}{l}\text { Suggested to be addend to the list of } \\
\text { priority substances (since } 31.01 .2012 \text { ) }\end{array}$ \\
\hline 1. Alachlorine & 1. AMPA & A. Plant preservatives: \\
\hline 2. Anthracene & 2. Bentazone & 1. Aclonifen \\
\hline 3. Atrazine & 3. Bisphenol-A & 2. Bifenox \\
\hline 4. Benzene & 4. Dicofol & 3. Cypermethrin \\
\hline 5. bromium diphenylether & 5. EDTA & 4. Dicofol \\
\hline 6. cadmium and its compounds & 6. Free cyanide & 5. Heptachlor \\
\hline 7. C10-13chloralcanes & 7. Glyphosate & 6. Quinoxyfen \\
\hline 8. Chlorfenwinfos & 8. Mecoprop (MCPP) & B. Biocidal substances: \\
\hline 9. Chlorpiryfos (ethyl chlorpiryfos) & 9..Musk xylene & 1. Cibutrin \\
\hline 10. 1,2-dichloroetan & 10. Perflurooctanesulfonic acid & 2. Dichlorovos \\
\hline 11. Dichloromethane & 11. Quinoxyfen & 3. Terbutryn \\
\hline 12. DEHP & 12. Dioxins & C. Industrial chemical compounds \\
\hline 13. Diuron & & 1. PFOS \\
\hline 14. Endosulfan & & 2. HBCDD \\
\hline 15. Fluoranten & & D. Combustion by-products: \\
\hline 16. Hexachlorbenzene & & 1. Dioxins and digoxin-derivates \\
\hline 17. Hexachlorbutadiene & & E. Substances of pharmaceutical \\
\hline 18. Hexachlorcycloheaane & & industry \\
\hline 19. Isoproturon & & 1. 17 alpha-ethynylestradiol (EE2) \\
\hline 20. Lead and its compounds & & 2. 17 beta-estradiol (E2) \\
\hline 21. Mercury and its compounds & & 3. diclofenac \\
\hline 22. Naphthalene & & \\
\hline 23. Nickel and its compounds & & \\
\hline 24. Nonylphenol & & \\
\hline 25. Octylphenol & & \\
\hline 26. Pentachlorbenzene & & \\
\hline 27. Pentachlorophenol & & \\
\hline 28. Simazine & & \\
\hline 29. Tributyltin compounds & & \\
\hline 30. Trichlorbenzenes & & \\
\hline 31. Trichloromethane (chloroform) & & \\
\hline 32. Trifluralin & & \\
\hline
\end{tabular}


Table 2. Concentrations and determination methods of active substances of the selected drugs in environmental samples

\begin{tabular}{|c|c|c|c|c|c|c|c|c|c|}
\hline \multirow[b]{2}{*}{ Group } & \multirow[b]{2}{*}{ Active substance } & \multirow{2}{*}{$\begin{array}{c}\text { Effects on } \\
\text { humans } \\
\text { or selected } \\
\text { pathogens }\end{array}$} & \multirow{2}{*}{ Sample } & \multirow[b]{2}{*}{$\begin{array}{l}\text { Collection } \\
\text { site }\end{array}$} & \multicolumn{3}{|c|}{ Method of determination } & \multirow{2}{*}{$\begin{array}{c}\text { Concentration } \\
\text { detected }\end{array}$} & \multirow{2}{*}{ Source } \\
\hline & & & & & Preparation & $\begin{array}{c}\text { Chromatographic } \\
\text { technique }\end{array}$ & Detector & & \\
\hline \multirow{13}{*}{$\begin{array}{l}\text { Non-steroidal } \\
\text { anti- } \\
\text { inflammatory } \\
\text { drugs }\end{array}$} & \multirow[b]{5}{*}{ Diclofenac } & \multirow{5}{*}{$\begin{array}{l}\text { Derivative of } \\
\text { aminophenol } \\
\text { acetic acid of } \\
\text { strong anti- } \\
\text { inflammatory, } \\
\text { analgesic and } \\
\text { antipyretic action. } \\
\text { It acts mainly } \\
\text { by inhibiting } \\
\text { cyclooxygenases: } \\
\text { constitutive } \\
\text { COX-1, } \\
\text { responsible for } \\
\text { synthesis of } \\
\text { prostaglandins } \\
\text { of physiological } \\
\text { functions } \\
\text { rather than } \\
\text { induced COX- } \\
2 \text {, responsible } \\
\text { for synthesis of } \\
\text { pro-inflammatory } \\
\text { prostaglandins } \\
\text { at the site of } \\
\text { inflammation }\end{array}$} & $\begin{array}{l}\text { Surface } \\
\text { water }\end{array}$ & Germany & SPE & \multirow{4}{*}{$\mathrm{GC}$} & $\begin{array}{c}\text { MS } \\
\text { MS/MS }\end{array}$ & $0.05 \mu \mathrm{g} / \mathrm{dm}^{3}$ & [66] \\
\hline & & & $\begin{array}{l}\text { Surface } \\
\text { water }\end{array}$ & USA & SPE & & MS & $10 \mu \mathrm{g} / \mathrm{dm}^{3}$ & [67] \\
\hline & & & $\begin{array}{l}\text { Surface } \\
\text { water }\end{array}$ & Switzerland & LLE & & MS & $12 \mathrm{ng} / \mathrm{dm}^{3}$ & [69] \\
\hline & & & Potable water & Germany & SPE & & MS & $0.4-0.9 \mu \mathrm{g} / \mathrm{dm}^{3}$ & [68] \\
\hline & & & Sewage & Canada & SPE & HPLC & ESI-MS & $10-20 \mathrm{ng} / \mathrm{dm}^{3}$ & [48] \\
\hline & \multirow{4}{*}{ Naproxen } & \multirow{4}{*}{$\begin{array}{l}\text { Derivative of } \\
\text { naphthaleneacetic } \\
\text { acid showing } \\
\text { anti-inflammatory } \\
\text { and antipyretic } \\
\text { effects. It } \\
\text { acts mainly } \\
\text { by inhibiting } \\
\text { Cyclooxygenase } \\
\text { COX-1 rather } \\
\text { than COX-2, }\end{array}$} & $\begin{array}{l}\text { Surface } \\
\text { water }\end{array}$ & Germany & $\begin{array}{l}\text { LLE } \\
\text { SPE }\end{array}$ & HPLC & $\begin{array}{l}\text { CE-MS } \\
\text { MS }\end{array}$ & $0.5 \mu \mathrm{g} / \mathrm{dm}^{3}$ & [70] \\
\hline & & & $\begin{array}{l}\text { Surface } \\
\text { water }\end{array}$ & Germany & SPE & \multirow[b]{2}{*}{$\mathrm{GC}$} & $\begin{array}{c}\text { MS } \\
\text { MS/MS }\end{array}$ & $0.39 \mu \mathrm{g} / \mathrm{dm}^{3}$ & [66] \\
\hline & & & $\begin{array}{l}\text { Surface } \\
\text { water }\end{array}$ & USA & SPE & & MS & $10 \mu \mathrm{g} / \mathrm{dm}^{3}$ & [71] \\
\hline & & & Sewage & Canada & SPE & HPLC & ESI-MS & $5-20 \mathrm{ng} / \mathrm{dm}^{3}$ & [48] \\
\hline & \multirow{4}{*}{ Ibuprofen } & \multirow{4}{*}{$\begin{array}{l}\text { Derivative } \\
\text { of propionic } \\
\text { acid of anti- } \\
\text { inflammatory, } \\
\text { analgesic and } \\
\text { antipyretic } \\
\text { effects. Action as } \\
\text { above }\end{array}$} & $\begin{array}{l}\text { Surface } \\
\text { water }\end{array}$ & Switzerland & SPE & $\mathrm{GC}$ & MS & $0.1-1.0 \mu \mathrm{g} / \mathrm{dm}^{3}$ & [69] \\
\hline & & & Sewage & Canada & SPE & HPLC & ESI-MS & $5-20 \mathrm{ng} / \mathrm{dm}^{3}$ & [48] \\
\hline & & & $\begin{array}{l}\text { Surface } \\
\text { water }\end{array}$ & Germany & $\begin{array}{l}\text { LLE } \\
\text { SPE }\end{array}$ & HPLC & $\begin{array}{l}\text { CE-MS } \\
\text { MS }\end{array}$ & $0.6 \mu \mathrm{g} / \mathrm{dm}^{3}$ & [70] \\
\hline & & & Sea water & North Sea & LLE & $\mathrm{GC}$ & MS & $0.6 \mathrm{ng} / \mathrm{dm}^{3}$ & [72] \\
\hline
\end{tabular}




\begin{tabular}{|c|c|c|c|c|c|c|c|c|c|}
\hline \multirow{6}{*}{$\begin{array}{l}\text { Steroid } \\
\text { hormones }\end{array}$} & \multirow[b]{2}{*}{ Estrone } & \multirow{2}{*}{$\begin{array}{l}\text { Ketone-hydroxyl } \\
\text { derivative of } \\
\text { estrane. A steroid } \\
\text { estrogen- effects } \\
\text { similar to } \\
\text { estradiol. . }\end{array}$} & $\begin{array}{l}\text { Surface } \\
\text { water }\end{array}$ & USA & SPE & $\mathrm{GC}$ & MS & $0,01 \mu \mathrm{g} / \mathrm{dm}^{3}$ & [71] \\
\hline & & & Sludge & Germany & $\begin{array}{l}\text { LLE } \\
\text { SPE }\end{array}$ & $\begin{array}{c}\text { HPLC } \\
\text { GC }\end{array}$ & MS & $0.02 \mu \mathrm{g} / \mathrm{dm}^{3}$ & [74] \\
\hline & & $\begin{array}{l}\text { The most potent } \\
\text { form of estrogen } \\
\text { in mammals. } \\
\text { In humans, it is }\end{array}$ & Sludge & Germany & $\begin{array}{l}\text { LLE } \\
\text { SPE }\end{array}$ & $\begin{array}{l}\text { LLE } \\
\text { SPE }\end{array}$ & MS & $0.02 \mu \mathrm{g} / \mathrm{dm}^{3}$ & [73] \\
\hline & $17 \beta$ - estradiol & $\begin{array}{l}\text { produced mainly } \\
\text { by ovaries and } \\
\text { placenta. It is also } \\
\text { produced by the } \\
\text { adipose tissue in } \\
\text { men and women } \\
\text { after menopause. }\end{array}$ & $\begin{array}{l}\text { Surface } \\
\text { water }\end{array}$ & Poland & SPE & HPLC & $\begin{array}{l}\text { DAD } \\
\text { UV }\end{array}$ & $0,51 \mathrm{ng} / \mathrm{dm}^{3}$ & [73] \\
\hline & & $\begin{array}{l}\text { Synthetic } \\
\text { estrogen, a } \\
\text { component of }\end{array}$ & $\begin{array}{l}\text { Surface } \\
\text { water }\end{array}$ & Poland & SPE & & $\begin{array}{c}\text { UV } \\
\text { DAD }\end{array}$ & $0.47 \mathrm{ng} / \mathrm{dm}^{3}$ & [73] \\
\hline & $\begin{array}{l}17 \alpha- \\
\text { ethynylestradiol }\end{array}$ & $\begin{array}{l}\text { contraceptives } \\
\text { It reptlaces } \\
\text { physiological } \\
\text { estrogens, whose } \\
\text { production is } \\
\text { inhibited during } \\
\text { the use of such } \\
\text { drugs }\end{array}$ & Sludge & Germany & $\begin{array}{l}\text { LLE } \\
\text { SPE }\end{array}$ & $\begin{array}{l}\text { LLE } \\
\text { SPE }\end{array}$ & MS & $0.09 \mu \mathrm{g} / \mathrm{dm}^{3}$ & {$[74]$} \\
\hline & Sulphonamides & $\begin{array}{l}\text { Sulfanilic acid } \\
\text { amides are ana- } \\
\text { logues of PABA, } \\
\text { competitively } \\
\text { inhibit the action } \\
\text { of the enzyme } \\
\text { synthesising dihy- } \\
\text { drofolic acid. }\end{array}$ & $\begin{array}{l}\text { Surface } \\
\text { water }\end{array}$ & USA & SPE & HPLC & MS & $0.07-15 \mu \mathrm{g} / \mathrm{dm}^{3}$ & {$[37]$} \\
\hline $\begin{array}{l}\text { Antibacterial } \\
\text { drugs }\end{array}$ & Trimethoprim & $\begin{array}{l}\text { Chemotherapeu- } \\
\text { tic agent inhibit- } \\
\text { ing dihydrofolic } \\
\text { acid reductase }\end{array}$ & Sea water & - & $\begin{array}{l}\text { LLE } \\
\text { SPE }\end{array}$ & & APCI-MS & $2.5 \mu \mathrm{g} / \mathrm{dm}^{3}$ & {$[75]$} \\
\hline & Sulfadiazines & $\begin{array}{l}p \text {-amino-ben- } \\
\text { zenesulfonic acid } \\
\text { amide used as } \\
\text { a bacteriostatic } \\
\text { agent. }\end{array}$ & Sea water & - & $\begin{array}{l}\text { LLE } \\
\text { SPE }\end{array}$ & HPLC & APCI-MS & $2.5 \mu \mathrm{g} / \mathrm{dm}^{3}$ & [75] \\
\hline & & $\begin{array}{l}\text { Drug reducing } \\
\text { the level of lipids }\end{array}$ & Sea water & North Sea & LLE & & MS & $0.013 \mu \mathrm{g} / \mathrm{dm}^{3}$ & {$[72]$} \\
\hline $\begin{array}{l}\text { regulating } \\
\text { lipid } \\
\text { metabolism }\end{array}$ & Clofibric acid & $\begin{array}{l}\text { high levels of } \\
\text { triglycerides and } \\
\text { cholesterol in } \\
\text { blood. }\end{array}$ & $\begin{array}{l}\text { Surface } \\
\text { water }\end{array}$ & Germany & SPE & GC & FID & $0.049 \mu \mathrm{g} / \mathrm{dm}^{3}$ & {$[68]$} \\
\hline
\end{tabular}




\section{References:}

1. R. Loos G, Locoro S, Comero S, Contini D, Schwesig F, Werres, et al. Pan-European survey on the occurrence of selected polar organic persistent pollutants in ground water. Water Res, 2010; 44: 4115-4126.

2. Kreuzinger N, Clara M, Strenn B, Vogel B. Investigation on the behaviour of selected pharmaceuticals in the groundwater after infiltration of treated wastewater. Wa. Sci. Technol. 2004; 52:221-228.

3. Hirsch R, Ternes T, Haberer K, Kratz K-L. Occurrence of antibiotics in the aquatic environment. Sci Tot Environ. 1999; 225: 109-118.

4. Aherne GW, Briggs R. The relevance of the presence of certain synthetic steroids in the aquatic environment. J. Pharm. Pharmacol. 1989;41:735-736.

5. Hignite C, Azarnoff DL. Drugs and drug metabolites as environmental contaminants: chlorophenxoyisobutyrate and salicylic acid in sewage water effluent. Life Sci. 1977;20:337-342.

6.Halling-Sørensen B, Nielsen SN, Lanzky PF, Ingerslev F, Lutzheft HCH, Jørgensen SE. Occurrence, fate and effects of pharmaceutical substances in the environment e a review. Chemosphere. 1998;36 (2):357-393.

7. Kim S, Aga DS. Potential ecological and human health impacts of antibiotics and antibioticresistant bacteria from wastewater treatment plants. J. Toxicol. Environ. Health e Part B, 2007; 10 (8):559-573.

8. Kümmerer K. Pharmaceuticals in the environment: scope of the book and introduction. Pharmaceuticals in the environment: sources, fate, effects and risks. Second edition. Berlin, Germany: Springer; 2004:3-11.

9.Breton R, Boxall A. Pharmaceuticals and personal care products in the environment: Regulatory drivers and research needs. QSAR \& Combinatorial Sci, 2003; 22: 399-409.
10. Daughton CG, Ternes TA. Pharmaceuticals and personal care products in the environment: agents of subtle change?, Environ. Health Perspec. 1999;107:907-938.

11. Fent K, Weston AA, Caminada D. Ecotoxicology of human pharmaceuticals. Aquat Toxicol. 2006;76:122-159

12. Kashiwada S, Ishikawa H, Miyamoto N, Ohnishi Y, Magara Y. Fish test for endocrine-disruption and estimation of water quality of Japanese rivers. Water Res. 2002;36: 2161-2166.

13. Jobling S, Nolan M, Tyler CR, Brighty G, Sumpter JP, Widespread sexual disruption in wild fish. Environ. Sci. Techno. 1998;32: 2498-2506.

14. Dudziak M, Luks-Betlej K, Ocena obecności estrogenów-steroidowych hormonów płciowych w wybranych wodach rzecznych w Polsce. Ochrona Środowiska. 2004; 26: 21-24

15. Ferriera da Silva B, Jelic A, Lopez-Serna R, Mozeto A, Petrovic M, Barcelo D. Occurrence and distribution of pharmaceuticals in surface water, suspended solids and sediments of the Ebro river basin, Spain. Chemosphere. 2011;85: 1331-1339.

16. Brausch JM, Connors KA, Brooks BW, Rand GM., Human pharmaceuticals in the aquatic environment: a review of recent toxicological studies and considerations for toxicity testing. Rev. Environ. Contam. Toxicol. 2012;218: 1-99.

17. Huerta B, Rodriguez-Mazaz S, Barcelo D, Pharmaceuticals in biota in the aquatic environment: analytical methods and environmental implications. Anal. Biochem. 2012;404: 2611-2624.

18. Brodin T, Fick J, Johnsson M, Klaminder J. Dilute concentrations of a psychiatric drug alter behaviour of fish from natural populations. Science. 2013; 339: 814-815.

19. Metcalfe CD. Pharmaceutical contaminants of emerging concern in the environment. Environ. Toxicol. Chem. 2013; 32: 1683-1684. 
20. Brain RA, Hanson ML, Solomon KR, Brooks B. Aquatic plants exposed to pharmaceuticals; effects and risk. Rev. Environ. Contam. Toxicol. 2008; 192: 67-115.

21. Schwaiger J, Ferling H, Mallow U, Wintermayr $\mathrm{H}$, Negele RD. Toxic effects of the non-steroidal anti-inflammatory drug diclofenac. Part I. Histopathological alterations and bioaccumulation in rainbow trout. Aquat. Toxicol. 2004;68 (2): 141-150.

22. Ternes T.A., Occurrence of drugs in German sewage treatment plants and rivers, Water Res. 1998; 32: 3245-3260.

23. Ternes TA, Stumpf M, Schuppert B, Haberer K. Simultaneous determination of antiseptics and acidic drugs in sewage and river water. Vom Wasser, 1998; 90: 295-309.

24. Farre' M, Ferrer I, Ginebreda A, Figueras M, Olivella L, Tirapu L, Vilanova M, Barcelo D. Determination of drugs in surface water and wastewater samples by liquid chromatographymass spectrometry: methods and preliminary results including toxicity studies with Vibrio fischeri. J. Chromatogr. 2002; 938: 187-197.

25. Heberer Th, Fuhrmann B, Schmidt-Baumler K, Tsipi D, Koutsouba V, Hiskia A. Occurrence of pharmaceutical residues in sewage, river, ground and drinking water in Greece and Germany. In: Daughton, CG, Jones- Lepp, T. (Eds.), Pharmaceuticals and Personal Care Products in the Environment: Scientific and Regulatory Issues. Symposium Series 791/2001, American Chemical Society, Washington DC, 70-83.

26. Heberer Th. Tracking down persistent pharmaceutical residues from municipal sewage to drinking water. In: Grischek, Th., Hiscock, K. (Eds.), Attenuation of Groundwater Pollution by Bank Filtration. J. Hydrol 2002.

27. Kolpin DW, Furlong ET, Meyer MT, Thruman EM.Pharmaceuticals, Hormones and Other Organic Wastewater Contaminations in U.S
Streams 1999-2000, A National Reconnaissance 2002: 1202-1211.

28. Stumpf M, Ternes TA, Wilken RD, Rodrigues SV, Baumann W. Polar drug residues in sewage and natural waters in the state of Rio de Janeiro, Brazil, Sci. Total Environ. 1999;225: 135-141.

29. Zwiener C, Frimmel FH. Oxidative treatment of pharmaceuticals in water. Water Res. 2000;34: 1881-1885.

30. Buser HR, Muller MD, Theobald N. Occurrence of the pharmaceutical drug clofibric acid and the herbicide mecoprop in various Swiss lakes and in the North Sea. Environ. Sci. Technol.1998;32: 188-19.

31. Heberer Th, Dunnbier U, Reilich Ch, Stan HJ. Detection of drugs and drug metabolites in groundwater samples of a drinking water treatment plant. Fresenius Environ. Bull. 1997; 6: 438-443.

32. Werres F, Stien J, Balsaa P, Schneider A, Winterhalter $\mathrm{P}$, Overath H. Automatisierte Bestimmung polarer Arzneimittelruckstande in Wassern mittels Festphasenmikroextraktion (SPME) und Derivatisierung. Vom Wasser. 2000; 94: 135-147.

33. Stumpf M, Ternes Th, Haberer K, Baumann W. Isolation of ibuprofen-metabolites and their importance as pollutants of the aquatic environment. Vom Wasser. 1998; 91: 291-303.

34. Buser HR, Poiger T, Muller MD. Occurrence and environmental behavior of the pharmaceutical drug ibuprofen in surface waters and in wastewater. Environ. Sci. Technol. 1999; 33: 2529-2535.

35. Hirsch R, Ternes T, Haberer K, Kratz KL. Occurrence of antibiotics in the aquatic environment.Sci. Total Environ. 1999;225: 109-118.

36. Alder AC, McArdell CS, Golet EM, Ibric S0, Molnar E, Nipales NS, Giger W. Occurrence and fate of fluoroquinolone, macrolide, and sulfonamide antibiotics during wastewater treatment and in ambient waters in Switzerland. In: Daughton, C.G., Jones-Lepp, T. (Eds.), Pharmaceuticals 
and Personal Care Products in the Environment: Scientific and Regulatory Issues. Symposium Series 791/2001, American Chemical Society, Washington DC, pp. 56-69.

37. Lindsey ME, Meyer M, Thurman EM. Analysis of trace levels of sulfonamide and tetracycline antimicrobials in groundwater and surface water using solid-phase extraction and liquid chromatography/mass spectrometry. Anal. Chem. 2001;73:4640-4646.

39. Carballa M, Omil F, Lema JM, Comparison of predicted and measured concentration of selected pharmaceuticals, fragrances and hormones in Spanish sewage. Chemosphere. 2008; 72: 11181123.

40. Backe WJ, Ort Ch, Brewer AJ, Fidel JA. Analysis of androgenic steroids In environmental waters by large-volume injection liquid chromatography tandem mass spectrometry, Anal. Chem. 2001; 83: $2622-2630$

41. Martín J, Camacho-Muñoz D, Santos JL, Aparicio I, Alonso E. Distribution and temporal evolution of pharmaceutically active compounds alongside sewage sludge treatment. Risk assessment of sludge application onto soils. J. Environ. Manage. 2012;102:18-25.

42. Miao XS, Yang JJ, Metcalfe CD. Carbamazepine and its metabolites in wastewater and in biosolids in a municipal wastewater treatment plant. Environ. Sci. Technol. 2005; 39: 7469-7475

43. McClellan K, Halden RU. Pharmaceuticals and personal care products in archived U.S. Biosolids from the 2001 EPA National Sewage Sludge Survey. Water Res. 2010;44: 658-68.

44. Gao P, Mao D, Luo Y, Wang, Xu B, Xu L. Occurrence of sulfonamide and tetracycline-resistant bacteria and resistance genes in aquaculture environment. Water Res. 2012; 46: 2355- 2364.

45. Yu Y, Huang Q, Cui J, Zhang K, Tang C, Peng $\mathrm{X}$. Determination of pharmaceuticals, steroid hormones, and endocrine-disrupting personal care products in sewage sludge by ultra-highperformance liquid chromatography-tandem mass spectrometry. Anal. Biochem. 2011;399(2):891-902.

46. Williams ES, Brooks BW. Human health risk assessment for pharmaceuticals in the environment: existing practice, uncertainty, and future directions. Hum. Pharm. Environ. (Emerging Topics in Ecotoxicology). 2012; 4: 167-224.

47. Ternes TA. Pharmaceuticals and metabolites as contaminants of the aquatic environment. Pharmaceuticals and Personal Care Products in the Environment: Scientific and Regulatory Issues. Symposium Series 791, American Chemical Society, Washington DC,39-54.

48. Miao XS, Koeing BG, Metcalfe CD, Analysis of acidic drugs in the effluents of sewage treatment plants using liquid chromatography- electrospray ionization tandem mass spectrometry. $J$. Chromatogr. A. 2002; 952(1-2): 139-147.

49. Fatta D, Nikolaou A, Achilleos A, Meric S. Analytical methods for tracing pharmaceutical residues in water and wastewater, Trends Anal. Chem. 2004;26(6): 515-533.

50. Jos A., Repetto G., Rios JC., Hazen MJ., Molero ML., del Peso A., et al. Ecotoxicological evaluation of carbamazepine using six different model systems with eighteen endpoints. Toxicol in Vitro. 2003;17: 525-32.

51. Łomotowski J, Szpindor A. Nowoczesne systemy oczyszczania ścieków. Arkady. 1999.

52. Tambosi JL, Felix de Sena R, Favier M, Gebhardt W José HJ, Schröder HF, Regina de Fátima Peralta Muniz Moreira: Removal of pharmaceutical compounds in membrane bioreactors (MBR) applying submerged membranes. Desalination 2010.

53. Noworyta A..Reaktor membranowy do biodegradacji lotnych substancji organicznych. Czasopismo Techniczne. 2008; 2 
54. Pedrouzo M, Borrull F, Pocurull E, Marce RM. Presence of pharmaceuticals and hormones in water from sewage treatment plants. Water, Air, Soil Pollut. 2011; 217: 267-281.

55. Czech B. Zastosowanie metod fotokatalitycznych w ochronie środowiska W: Nauka i przemysł: metody spektroskopowe w praktyce, nowe wyzwania i możliwości: praca zbiorowa Lublin: Uniwersytet Marii Skłodowskiej-Curie w Lublinie. Wydział Chemii, 2010; 525-530.

56. Carp O, Huisman CL, Reller A. Photoinduced reactivity of titanium dioxide. Prog. Solid State Chem. 2004; 32; 33-177.

57. Wang Ch, Shi H, Adams CD, Timmons T, Ma Y. Investigation of pharmaceuticals in Missouri natural and drinking water using high performance liquid chromatography-tandem mass spectrometry, Water Res. 2011;. 2: 142.

58. Mestre AS, Pires J, Nogueira JMF, Carvalho AP. Activated carbons for the adsorption of ibuprofen. Carbon. 2007; 45: 1979.

59. OnalY,Akmil-BasarC, Sarici-Ozdemir C. Elucidation of the naproxen sodium adsorption onto activated carbon prepared from waste apricot: Kinetic, equilibrium and thermodynamic characterization, J. Hazard. Mater. 2007; 14: 727-734.

60. Serrano D, Suarez S, Lema JM, Omil F. Water Res., Anaerobic treatment of fibreboard manufacturing wastewaters in a pilot scale hybrid usbf reactor. Water Res. 2001; 45: 5323.

61. Ho L, Grasset C, Hoefel DL, Dixon MB, Leusch FDL, Newcombe G, Saint CP, Brookes JD. Assessing granular media filtration for the removal of chemical contaminants from wastewater.Water Res. 2011; 45: 3461.

62. Cabrera-Lafaurie WA, Roman FR, HernandezMaldonado AJ. Transition metal modified and partially calcined inorganic-organic pillared clays for the adsorption of salicylic acid, clofibric acid, carbamazepine, and caffeine from water. $J$. Colloid Interface Science. 2012; 15:381-391.
63. Han J, Qiu W, Meng S, Gao W. Water Res. Removal of ethinylestradiol (EE2) from water via adsorption on aliphatic polyamides. 2012; 46: 5015-5724.

64. Rivera-Jimenez SM, Hernandez-Maldonado AJ. Nickel(II) grafted MCM-41: A novel sorbent for the removal of Naproxen from water, Micropor. Mesopor. Mat. 2008;116: 246.

65. DYREKTYWA PARLAMENTU EUROPEJSKIEGO I RADY 2013/39/UE z dnia 12 sierpnia 2013 r. zmieniająca dyrektywy 2000/60/WE i 2008/105/WE w zakresie substancji priorytetowych w dziedzinie polityki wodnej (Tekst mający znaczenie dla EOG)

66. Ternes TA., Analytical methods for the determination of pharmaceuticals in aqueous environmental samples, Trends in Anal. Chem.2001; 20(8) .

67. Ollers S, Singer HP, Fassler P, Muller Sr. Simultaneous qualification of neutral and acidic pharmaceuticals and pesticides at low-ng/1 level in surface and waste water, J. Chromatogr A. 2001;911: 225-235.

68. Ternes TA, Meisenheimer M, McDowell D, Sacher F, Brauch Hj, Haist-Gulde B, Preuss G, Wilme U, Zulei-Seibert S, Removal of Pharmaceuticals during Drinking Water Treatment. Environ. Sci. Technol. 2002; 36(17): 3855-3863.

69. Buser HR, Poiger T, Muller MD, Occurrence and fate of pharmaceutical drug diclofenac in surface waters: Rapid photodegradation in a lake. Environ. Sci. Technol. 1998; 32(22): 3449-3456.

70. Ahrer W, Buchlberger W, Analysis of acidic pharmaceutical drug residues in surface water by capillary electrophoresis- electrospray mass spectrometry. Am. Lab. 2001; 33(24): 31-35.

71. Hogenboom AC, Niessen WMA, Brinkman UAT, Rapid target analysis of microcontaminants in water by online single- short-column liquid chromatography combined with atmospheric pressure chemical ionization ion-trap mass spectrometry, $J$. Chromatogr A. 1998; 794(1-2): 201-210. 
72. Weigel S, Kuhlmann J, Huhnerfuss H, Drugs and personal care products as ubiquitous pollutants occurrence and distribution of clofibric acid, caffeine and DEET in the North Sea, Sci. Total Environ. 2002; 295(1-3): 131-141.

73. Zarzycki PK, Włodarczyk E, Baran MJ. Determination of endocrine disrupting compounds using temperature-dependent inclusion chromatography II. Fast screening of free steroids and related low-molecular-mass compounds fraction in the environmental samples derived from surface waters, treated and untreated sewage waters as well as activated sludge material, $J$. Chromatogr A. 2009; 1216: 7612-7622.
74. Ternes TA, Andersen H, Gilberg D, Bonerz $\mathrm{M}$, Determination of estrogens in sludge and sediments by liquid extraction nad GC/MS/MS . Anal. Chem. 2002; 74(14): 3498-3504.

75. Sorensen LK, Hansen H. Determination of sulfadiazine and timethoprim in marine sediment by LC-APCI-MS, J. Liq. Chromatogr. Related Technol. 2002; 25(7): 1063-1075.

\section{Correspondence address:}

Prof. Paweł K. Zarzycki, PhD

Department of Toxicology and Bioanalytics, Koszalin University of Technology Śniadeckich 2a, Koszalin, Poland 